\title{
An Analysis on Task Division of Household Sanitation Management in Dense Settlements in Binjai North Sumatera Province
}

\author{
Evi Naria ${ }^{1}$, Heru Santosa ${ }^{2}$ Nurmaini $^{3}$, and Kintoko Rochadi ${ }^{4}$ \\ \{evi3@usu.ac.id ${ }^{1}$, heru_php2@yahoo.com ${ }^{2}$, nurmainik@yahoo.com ${ }^{3}$, kintokorochadi@gmail.com $\left.{ }^{4}\right\}$ \\ Faculty of Public Health, Universitas Sumatera Utara, Medan, Indonesia ${ }^{1234}$
}

\begin{abstract}
The quality of sanitation in households has not met the requirements of the health standard. The main agent of household sanitation is mother. It has not been firmly determined about the role of each family member in household sanitation management. This quasi-experimental research involved 30 households. The sanitation tasks were carried out by mother, father, and children according to the family agreement. Data were analyzed used paired t-test at a 95\% CI. The result showed that division of household tasks gave significant effects: toilet is no longer breeding place for vectors $(\mathrm{p}=0.023)$, toilet is cleaned every day $(\mathrm{p}=0.000)$, and some waste was reused $(\mathrm{p}=0.010)$, and trash was disposed every day $(\mathrm{p}=0.023)$. All families are willing to carry out the household management tasks. The task division to all family members has improved the quality of sanitation in household.
\end{abstract}

Keywords: Household sanitation, Sanitation task division, Sanitation management

\section{Introduction}

Sanitation is an attempt to cultivate clean living habit in preventing direct contact between human and organisms or materials which can cause diseases, in order to maintain human health. The implementation of sanitation in the community includes clean water supply, waste management, toilet management, and pollution [1]. Inadequate sanitation causes inconveniences and risks to environmental-based diseases such as worm diseases and diarrhea. Sanitation risk factors that significantly affect diarrheal diseases among children under five are the use of toilet (1.87 times), waste management (1.42 times), and handwashing with soap (1.77 times), that provides lower risks to diarrheal diseases compared to children who have not used toilet and washed hand without soap [2]. Adequate sanitation could minimize the risks of diarrheal diseases in children by up to $95 \%$ [3]. During this pandemic, qualified sanitation management is needed to prevent the growth and development of pathogenic microorganisms such as Covid19.

The areas where inadequate sanitation is often found in dense settlements. The result of research on the condition of household sanitation in dense settlements in Binjai City found that (1) $99.5 \%$ of households owned toilet, (2) feces were found in $81.2 \%$ of houses, (3) $39.1 \%$ of the households had dirty toilet floors, (4) cleaning equipment were unavailable in $15.3 \%$ of the households although most households had sufficient clean water supplies, (5) waste was taken and collected by cleaning officers in $29.7 \%$ of households, (6) $49.5 \%$ of households burned their waste, (7) $67.3 \%$ of households had no trash cans, (8) flies were found around the garbage 
$(60.44 \%)$, and dirty drinking water container $(40.1 \%)$. Most households owned sanitation facilities, yet sanitation maintenance has not optimal yet.

Sanitation management starts in the household as the smallest unit that manages and practices sanitation. Household sanitation management includes provision, utilization, and maintenance of sanitation facilities. The provision of sanitation facilities in the households is independently done according to the family capability. The utilization of sanitation facilities is optimally carried out by all family members [4]. The maintenance of the sanitation facilities is carried out to ensure the facilities are convenient and worth using. Sanitation management in the households should be carried out by the whole family members. Based on the result of focus group discussion on improving the quality of sanitation, it is found that the household sanitation management is mostly done by mother. Mothers manage household sanitation especially in maintaining the sanitation facilities. Mothers frequently become lazy to manage household sanitation since they are tired after doing various tasks in the household. The other family members only help when mother asks for help [4] Whereas, family members are potential to be involved and empowered to help mother to manage sanitation in the household.

It is expected that sanitation management can be improved starting from the households. Research on an attempt to improve health sanitation behavior found several variables which provided significant effect: the participation of health cadres $(0.2 \%)$, family empowerment $(15.3 \%)$, and perception toward healthy habit $(9.9 \%)$. From the three variables, family empowerment provided the greatest effect in improving sanitation management in households [5].

Sanitation management in the household that concerns family empowerment is expected being an alternative approach to improve household sanitation. The whole family members should participate to improve the sanitation in the households, so the sanitation can fulfill the requirement of the health standard [6]. Research [6] examined family empowerment in improving family coping. The result showed that there were differences in the level of family coping in families who received intervention of family empowerment. The families who received intervention of family empowerment were better in identifying the family tasks, recognizing family health problems, and making a decision for necessary health actions.

Generally, the condition of sanitation in dense settlements do not meet the health standard. One of the factors affecting the sanitation condition is the sanitation task is mostly done by mother that makes mother sometimes tried to do the sanitation tasks. The other family members as household resources only help mother occasionally. Meanwhile, the whole family members need to be involved by dividing certain sanitation tasks to improve the household sanitation condition.

\section{Methodology}

This quasi-experimental research was conducted on 30 families with two criteria: (1) the families without housemaid service, and (2) having children older than 10 years old. The intervention given to the families was the sanitation task division including the toilet and waste management to each family member according to family agreement. The sanitation management tasks include sanitation facilities maintenance and waste management such as waste reuse, waste disposal, and trash cans cleaning. The stage of intervention implementation was started with observation on the condition of toilet and waste management. The intervention was given for 3 months. The data collected were information about the condition of household sanitation 
before and after intervention. The data were analyzed using Paired T-Test at $95 \%$ confidence interval.

\section{Result and Discussion}

The characteristics of the households who participated in this research are as follows:

Table 1. The Characteristics of Household Who Received Intervention of Task Division of Sanitation Management in Dense Settlements in Binjai City.

\begin{tabular}{|c|c|c|c|}
\hline \multicolumn{2}{|c|}{ Characteristics } & \multirow{2}{*}{$\begin{array}{c}\text { Number of Households } \\
9\end{array}$} & \multirow{2}{*}{$\begin{array}{c}\begin{array}{c}\text { Percentage } \\
(\%)\end{array} \\
30,0\end{array}$} \\
\hline \multirow{4}{*}{ Number of family members } & 3 persons & & \\
\hline & 4 persons & 6 & 20,0 \\
\hline & 5 persons & 10 & 33,4 \\
\hline & 6 persons & 5 & 16,6 \\
\hline \multirow{3}{*}{$\begin{array}{l}\text { Mothers' educational } \\
\text { background }\end{array}$} & Primary School & 5 & 16,7 \\
\hline & Junior High School & 6 & 20,0 \\
\hline & Senior High School & 18 & 60,0 \\
\hline \multirow{4}{*}{$\begin{array}{l}\text { Fathers' educational } \\
\text { background }\end{array}$} & Undergraduate & 1 & 3,3 \\
\hline & Primary School & 1 & 3,3 \\
\hline & Junior High School & 6 & 20,0 \\
\hline & Senior High School & 23 & 76,7 \\
\hline \multirow{3}{*}{ Home ownership status } & Owner & 8 & 26,7 \\
\hline & Renter & 11 & 36,7 \\
\hline & Relatives' home & 11 & 36,7 \\
\hline
\end{tabular}

Participant households consist of 3 to 6 family members. Based on the data of educational background, $60 \%$ of mothers and $76.7 \%$ of fathers graduated from Senior High School (SMA). The data of the homeownership status shows that $26.7 \%$ of household lives in their own house (owner), $36.7 \%$ of the households rent the house (renter), and other participants occupy the relative's house.

The intervention of task division was conducted by distributing tasks to maintain toilet and waste to all family members older than 10 years. The families were assisted to make an agreement on the division of sanitation tasks. The task division agreed by all family members was carried out by mother, father, and children. The conditions of household before and after making task division are as the following table.

Table 2. The Result of Observation of Toilet Management Before and After Intervention of Task Division in Household in Dense Settlements in Binjai City.

\begin{tabular}{|c|c|c|c|c|c|c|}
\hline \multirow{2}{*}{ No } & \multirow{2}{*}{ Observation } & \multicolumn{2}{|c|}{ Before intervention } & \multicolumn{2}{|c|}{ After intervention } & \multirow[b]{2}{*}{ p } \\
\hline & & Number & Percentage & Number & Percentage & \\
\hline 1 & $\begin{array}{l}\text { Households have their } \\
\text { own toilet }\end{array}$ & 30 & 100,0 & 30 & 100,0 & - \\
\hline 2 & $\begin{array}{l}\text { Households use goose } \\
\text { neck type toilet }\end{array}$ & 30 & 100,0 & 30 & 100,0 & - \\
\hline 3 & $\begin{array}{l}\text { Water supplies are } \\
\text { available. }\end{array}$ & 30 & 100,0 & 30 & 100,0 & - \\
\hline
\end{tabular}




\begin{tabular}{llccccc}
4 & $\begin{array}{l}\text { Hand soap is available in } \\
\text { toilet }\end{array}$ & 30 & 100,0 & 30 & 100,0 & - \\
5 & $\begin{array}{l}\text { Feces are not found } \\
\text { around house }\end{array}$ & 30 & 100,0 & 30 & 100,0 & - \\
6 & $\begin{array}{l}\text { Toilet is no longer } \\
\text { breeding place for }\end{array}$ & 25 & 83,3 & 30 & 100,0 & 0.023 \\
7 & $\begin{array}{l}\text { vectors toilets do not smell } \\
\begin{array}{l}\text { The toilet is cleaned every } \\
\text { day. }\end{array}\end{array}$ & 86,7 & 29 & 96,7 & 0.083 \\
\hline
\end{tabular}

The observation on the condition of toilets after intervention of task division found that sanitation management is better than before the intervention. Several conditions which overall had met the standard before intervention also met the standard after intervention in terms water supply in toilet, available soap in toilet, and no feces found around the house. Several improvements in toilet condition are: (1) latrine is no longer breeding place for mosquitos and insect from $83.3 \%$ to $100 \%$, (2) cleaning tools are available from $96.7 \%$ to $100 \%$, (3) the toilets do not smell from $86,7 \%$ to $96,7 \%$, (4) cleaning the toilet and the toilet floor every day from $20 \%$ to $80 \%$.

Table 3. The Result of Waste Management Before and After Intervention of Task Division

\begin{tabular}{|c|c|c|c|c|c|c|}
\hline \multirow{2}{*}{ No } & \multirow{2}{*}{ Observation } & \multicolumn{2}{|c|}{ Before intervention } & \multicolumn{2}{|c|}{ After intervention } & \multirow[b]{2}{*}{$\mathbf{p}$} \\
\hline & & Number & Percentage & Number & Percentage & \\
\hline 1 & Trash can is available. & 27 & 90,0 & 28 & 93,3 & 0.032 \\
\hline 2 & Trash can is watertight & 5 & 16,7 & 17 & 56,7 & 0.000 \\
\hline 3 & Trash can with cover & 0 & 0,0 & 16 & 53,3 & 0.000 \\
\hline 4 & $\begin{array}{l}\text { No waste left stuck on } \\
\text { the wall of the trash can }\end{array}$ & 16 & 53,3 & 27 & 90,0 & 0.000 \\
\hline 5 & Some waste is reused & 1 & 3,3 & 13 & 43,3 & 0.010 \\
\hline 6 & $\begin{array}{l}\text { Waste is disposed every } \\
\text { day }\end{array}$ & 24 & 80,0 & 29 & 96,7 & 0.023 \\
\hline 7 & $\begin{array}{l}\text { Waste is not scattered } \\
\text { around the house }\end{array}$ & 26 & 86,7 & 27 & 90,0 & 0.032 \\
\hline 8 & $\begin{array}{l}\text { Waste is disposed to } \\
\text { public landfill }\end{array}$ & 11 & 36,7 & 18 & 60,0 & 0.016 \\
\hline
\end{tabular}

The results of the observation on the household waste management after intervention of task division in sanitation management are generally better than before the intervention. Several improvements in the waste management are: (1) trash can is available from $90 \%$ to $93.3 \%,(2)$ trash can is watertight from 16.7 to $56.7 \%$, (3) trash can with cover from $0 \%$ to $53.3 \%$, (4) trash is disposed every day from $80 \%$ to $96,7 \%$, (5) Some waste is reused from $3.3 \%$ to $43.3 \%$, (6) household waste is disposed to public landfill from $36.7 \%$ to $60 \%$.

The result of t-test showed a significant influence in several aspects of toilet and waste management variables. Two significant differences found in the toilet management in which toilet is no longer breeding place for vectors $(\mathrm{p}=0.023)$ and families clean the toilet every day $(\mathrm{p}=0.000)$. Meanwhile, significant influences also found in waste management variable in which trash can with cover is available $(\mathrm{p}=0.000)$, trash can is watertight $(\mathrm{p}=0,000)$, no waste left 
stuck on the wall of the trash can $(p=0,000)$ some waste is reused $(p=0.010)$, and household waste is disposed every day ( $\mathrm{p}=0.023)$, waste is disposed to public landfill $(\mathrm{p}=0,016)$.

\section{Discussion}

The household sanitations managed with task division in toilet and waste management in several particular variables has improved after intervention. Task division encourages all family members to participate in household sanitation management, not as previously in which most sanitation tasks are carried out by mother. The improvement could be seen especially from the role and participation of human resources or family members in the household sanitation management. The improvement in the family occurs due to the encouragement to cooperate in managing sanitation together. The families have ability and willingness to participate in managing the basic sanitation in household. The families understand the essence of sanitation so they are willing to improve sanitation implementation in households. The family cooperates to do sanitation tasks. Thus, mother has time to rest.

Family resource management is conducted by involving all family members in identifying the family condition, formulating solutions, and providing opportunities to participate in household management. This condition is different from research on Family Resources Management in Bogor Regency which found that the practice of family resource management is generally not very influential. Yet, there are several factors provide positive effects such as quality of communication within the family and the family income [7] The toilets are also cleaner and they do not smell anymore. The household waste is disposed to a public landfill. Meanwhile, the numbers of family who disposed waste to river significantly decrease. Yet, the condition of sanitation facilities has not thoroughly met the health standard due to limited financial resource of families to build better sanitation facilities which meet the requirements of the health standard.

The households consist of 3 to 6 family members and most of the families rent a house or occupy their relative's house. The majority of educational level of father and mother is Senior High School (SMA) graduates so they could well receive the information and intervention given to the families. The households have material resource in form of basic sanitation facilities although their management and quality have not met the health standard. The division of sanitation tasks to all family members is an application of functioning the family itself. The agreement about the task division in managing the household sanitation has changed the perspective that sanitation tasks should be carried out by mother. Female and male in the family are responsible for managing household sanitation. Task division consists of cleaning the toilet and dispose of the trash. The task of sanitation management is divided to father, mother, and children. It no longer focuses on mother. Collaborative sanitation management has reduced mothers' workload. Numerous researches [6] [8] conducted on family empowerment in improving the family coping found that the family who received intervention of empowerment are better in identifying family tasks, recognizing family health problems, and making necessary health action.

The cleanliness of the toilets improves after giving task division to all family members. The number of family who clean the toilet every day has improved from $20 \%$ to $80 \%$. The toilets do not smell also increased to $96.7 \%$. Yet, only $46.7 \%$ of households owned septic tank, meanwhile, $53.3 \%$ disposed the feces to rivers or public sewage disposal. This condition could not be improved due to the limited land of families. Family empowerment has also improved 
knowledge and behavior of families so they can manage household waste such as sorting the waste, minimizing waste, and being motivated to join the garbage bank [9]. Sanitation conditions have changed after receiving intervention of task division: latrines are no longer a breeding place for vectors, toilet is cleaned every day, trash cans with cover are available, some household waste is reused, and waste is disposed every day. Thus, better sanitation condition which met the requirement of the health standard provide benefits for families. Sanitation facilities in households become more maintained and cleaner. Adequate sanitation has reduced the risks of contamination in the facilities, thus the risks of health problems in families has also been automatically reduced.

\section{Conclusion}

All family members are willing to do tasks in sanitation management. The task division in toilet and waste management can improve the quality of sanitation in household. Family toilet and waste management are better after receiving intervention of task division to the whole family members. Significant variables after intervention of task division are toilets are no longer breeding places for vectors, toilet is cleaned every day, trash can is watertight, no waste left stuck on the wall of the trash can, some waste is reused, and household waste is disposed every day, waste is disposed to public landfill.

\section{Acknowledgment}

The authors would like to give the highest appreciation for the support and information given by all participants and informants involved in this research, especially for the field assisting team collecting the data from the community in Binjai City, North Sumatera Province, Indonesia.

\section{References}

[1] Mundiatun, D: Environmental Health Management. Yogyakarta: Gava Media Press (2015)

[2] Azkiya. Z. Made Djaya I.: Factors Affecting the Incidence of Diarrhea in Under Five Years Old in Puskesmas Mekarwangi, Bogor, 2014. Faculty of Public Health Universitas Indonesia (2014)

[3] World Health Organization (WHO), "WHO estimates of the global burden of foodborne diseases: executive summary," WHO Exec. Summ., p. 257, (2015), [Online]. Available: http://www.who.int/foodsafety/publications/foodborne_disease/fergreport/en/

[4] E. Naria and Nurmaini: "Environmental-based Diseases Prevention by Improving Sanitation Quality in Binjai.," Medan, (2018)

[5] Martono and Satino: "Model of community health nursing care to accelerate mdgs on health sanitation behavior sector," Ners, vol. 10, no. 2, pp. 301-307, (2015)

[6] Ardian, I: Pemberdayaan Keluarga Meningkatkan Koping Keluarga Diabetes Militus Tipe 2. Jurnal Ilmu Keperawatan, 1(2). (2013)

[7] Herawati, Tin. Basita Ginting. Pang S Asngari. Djoko Susanto. Herien Puspitawati : Family Resources Management of Partisipants of Community Empowerment Program in Bogor Regency. Jurnal Penyuluhan. September 2011. Vol 7 No 2. Diakses 6 April 2020 (2011)

[8] T. B. Ratnasari and Ananti Destiari Prasanta: "Effect family empowerment in increasing family koping with diabetes mellitus type 2 in the krajan and krajan hamlet, glagahwerovillage, panti districts, jember regency,” Indones. J. Heal. Sci., no. September, pp. 141-144, (2018). 
[9] Ruhmawati, T. Dwi Tjahjani. Mimin Karmini: Model of Family Empowerment in Increasing Knowledge Attitude and Behaviour for Waste Management. Competitive Grant Research Report. Dept. of Environmental Health Poltekes Kemenkes Bandung (2016) 